\title{
HUBUNGAN POWER OTOT LENGAN DAN KOORDINASI MATA-TANGAN DENGAN HASIL SERVIS PANJANG DALAM PERMAIAN BULU TANGKIS PADA SISWA EXTRAKURIKULER SMA NEGERI 2 OKU
}

\author{
Daryono \\ Pendidikan Olahraga Universitas PGRI Palembang, Indonesia \\ e-mail: mrdary.ion@gmail.com
}

\begin{abstract}
Abstrak
Tujuan dari penelitian ini adalah untuk mengetahui hubungan antara power otot lengan dan koordinasi mata-tangan dengan hasil servis panjang dalam permainan bulu tangkis pada siswa ekstrakurikuler SMA Negeri 2 OKU. Metode pnelitian yang digunakan adalah metode korelasional yang bertujuan untuk mengetahui hubungan antar variabel. Populasi dalam penelitian ini berjumlah 20 siswa yang mengikuti ekstrakurikuler bulu tangkis di SMA Negeri 2 OKU, sedangkan sampel diambil secara total sampling sehingga peneitian ini memiliki sampel sebanyak 20 siswa. Instrument tes yang digunakan yaitu tes two-hand medicine ball put, Tes lempar tangkap bola tenis dan tes servis panjang. Teknik analisis data yang digunakan adalah teknik analisis korelasi product moment dan ganda. Hasil penelitian membuktikan bahwa ada hubungan antara power otot lengan dengan servis panjang, terbukti dengan koefesien korelasi sebesar 0,716 yang berdasarkan tabel penafsiran interpretasi korelasi memiliki hubungan sangat kuat. Ada hubungan antara koordinasi mata-tangan dengan servis panjang, terbukti dengan koefesien korelasi sebesar 0,512 yang berdasarkan tabel penafsiran interpretasi korelasi memiliki hubungan sedang. Ada hubungan power otot lengan dan koordinasi mata-tangan secara bersama-sama dengan servis panjang, terbukti dengan koefeisien korelasi ganda sebesar 0,736 yang berdasarkan tabel penafsiran interpretasi korelasi memiliki hubungan sangat kuat.
\end{abstract}

Kata-kata kunci : Power Otot Lengan, Koordinasi Mata-tangan, Servis Panjang

Abstract

The purpose of this study was to determine the relationship between muscle strength and eyehand with the results in badminton games on extracurricular students of OKU 2 State Senior High School. The research method used is a correlational method which aims to determine the relationship between variables. The population in this study were 20 students who participated in badminton extracurricular activities at SMA Negeri 2 OKU, while the total sampling sample of this Research City had a sample of 20 students. The test instruments used were two-handed ball tests, ball catching tests and long service tests. Data analysis techniques used are moment and double product modifications. The results of the study prove that there is a relationship between strength and unit, which is proven by 0.716 based on interpretation interpretation tables that have very strong relationships. There is a relationship between responsibility and long service, as evidenced by as much as 0.512 based on the interpretation table interpretation of medium expression. There are strength and mental relationships that work together with long service, as evidenced by the coefficient of a large number of 0.736 based on the interpretation interpretation table must have a very strong

Keywords : Power Arm Muscles, Eye-hand Coordination, Long Service 


\section{Pendahuluan}

Cabang olahraga bulu tangkis merupakan salah satu cabang olahraga yang cukup populer di Indonesia bahkan di dunia. Sejalan dengan perkembangan permainan bulu tangkis ini, juga ikut berkembang dengan metode-metode melatih yang baru yang lebih efektif dan efisien. Begitu banyak negara yang tidak diperhitungkan prestasinya saat ini dapat menghasilkan tim yang kompak dan cukup disegani, hal ini disebabkan karena tiaptiap tim mampu mengembangkan dan memanfaatkan potensi secara optimal.

Permainan bulu tangkis semakin berkembang terutama pada beberapa tahun terakhir. Cabang olahraga bulu tangkis dikenal tidak hanya sebagai olahraga prestasi, tetapi juga sebagai olahraga rekreasi. Perkembangan permainan bulu tangkis di Indonesia sangat cepat karena banyak dari masyarakat, khususnya pemuda yang menyukai permainan bulu tangkis tersebut. Terbukti dengan adanya gelanggang olahraga bulu tangkis yang disediakan baik itu oleh swasta maupun pemerintah.

Permainan bulu tangkis merupakan permainan yang memiliki keterampilan ataupun teknik-teknik yang banyak. Ada teknik servis, teknik mengembalikan bola atau drop shoot, dan teknik smash. Dan juga dalam bermain bulu ;tangkis pemain wajib memiliki kemampuan fisik atau kondisi fisik yang prima. Dan tidak lupa juga unsur psikis atau mental di saat bermain ataupun bertanding. Ke semua itu haruslah dimiliki oleh seorang pemain bulu tangkis karena sema itu saling beketerkaitan di dalam peningkatan kemampuan seseorang. Salah satu teknik yang penting didalam bermain bulu tangkis yaitu servis panjang.

Poole (2011: 21) menyatakan bahwa pukulan servis merupakan pukulan pertama yang mengawali suatu permainan bulu tangkis. Servis ada dua yaitu servis pendek (short service) dan servis panjang (servive lob). Servis pendek adalah pukulan yang melampaui jaring, dan langsung jatuh ke sisi lapangan lawan, dengan menjatuhkan sedekat mungkin dengan net sebatas garis servis pendek. Servis panjang merupakan kemampuan memukul bola dengan kuat dan tepat ke sasaran yang dituju yaitu di arah belakang permainan lawan. Servis panjang mudah dilaksanakan apabila para pemain memahami bagaimana teknikteknik didalam melakukan servis panjang. Pertama-tama pemain memegang bola di atas pusat, tangan ditarik kebelakang lalu ayunkan kebawah dan diarahkan kedepan lalu dipukul bola sekuat-kuatnya dengan menggunakan raket. Seandainya pemain tidak kuat melakukan pukulan maka kemungkinan bola tidak akan menyeberangi net. Bola akan tepat ke sasaran yang dituju haruslah memliki koordinasi antara mata dan tangan untuk saling berkolaborasi di dalam mengarahkan dan melakukan pukulan bola dalam servis.

Untuk menghasilkan servis panjang yang baik, ada banyak faktor-faktor yang mempengaruhi, pemain harus memiliki beberapa komponen kondisi fisik yang mendukung kemampuan. Diantaranya Power otot lengan dan koordinasi mata-tangan, power otot lengan merupakan kombinasi kekuatan dan kecepatan dengan ditandainya kontraksi otot lengan di dalam menggerakan tangan untuk melakukan pukulan yang kuat dan cepat. Sedangkan koordinasi mata-tangan merupakan kombinasi antara mata dan tangan untuk saling berhubungan didalam merespon gerakan yang akan dilakukan dan mengarahkan ke arah mana yang tepat untuk menyeberangkan bola ke area permainan lawan.

Hasil pengamatan awal peneliti dan informasi dari pelatih/guru beberapa kali di SMA Negeri 2 OKU, bahwa servis panjang yang dilakukan oleh siswa masih lemah. Karena arah bolanya belum menuju kesasaran, sehingga mudah dikembalikan dan di smash oleh pemain lawan.

Hal ini dikuatkan oleh penelitian yang dilakukan oleh Ghon Lisdiantoro (2016) yang menyatakan bahwa ada hubungan yang meyakinkan antara koordinasi mata tangan, power otot lengan dan kekuatan otot perut dengan kemampuan pukulan smash pada mahasiswa putra pembinaan prestasi universitas tunas pembangunan surakarta tahun 2013. (Fregresi $=$ $12,851>$ Ftabel $1 \%=4.64)$. Berdasarkan hasil analisis data didapat harga Fhitung lebih besar daripada harga Ftabel, sehingga hipotesis yang menyatakan bahwa, "Ada hubungan yang signifikan antara koordinasi mata tangan, power otot lengan dan kekuatan otot perut dengan kemampuan pukulan smash pada mahasiswa putra pembinaan prestasi IKIP PGRI MADIUN. Helda Heldayana (2016) menyatakan juga bahwa power otot lengan berperan 
dominan melakukan spike yaitu berperan pada kekuatan dan kecepatan pada saat melakukan spike, serta kemampuan memukul bola sekeras mungkin. Hal ini diharapkan, setiap pemain bola voli hendaknya selalu berupaya untuk meningkatkan power otot lengannya. Muharam Syuhada (2013) juga menyatakan bahwa Ada hubungan yang signifikan antara daya ledak otot lengan dan bahu, kekuatan otot tungkai dan koordinasi mata, tangan dengan kemampuan free throw pada siswa ekstrakurikuler bolabasket di SMA N 1 Ngemplak Sleman, dengan $R y(x 1 . x 2 \cdot x 3)=0,983>R(0.05)(20)=0,360$. Dengan demikian dapat disimpulkan bahwa sumbangan daya ledak otot lengan dan bahu, kekuatan otot tungkai dan koordinasi mata, tangan dengan kemampuan free throw sebesar $96,6 \%$ dan sisanya sebesar 3,4\% dipengaruhi oleh variabel lain.

Hal senada juga di ungkapkan Maulidin (2017) yang menyatakan bahwa nilai korelasi $r$ hitung yang dihasilkan dalam penelitian ini sebesar 0,906 , kemudian melihat nilai $r$ tabel dengan jumlah subyek 26 orang, pada taraf signifikan $5 \%$ dimana $r$ tabel menunjukan angka 0,338 . Kenyataan tersebut menunjukan bahwa nilai $r$-hitung berada di atas angka batas penolakan yaitu 0,906 >0,338. Maka Dengan demikian berarti hasil penelitian ini di nyatakan signifikan, artinya hipotesis alternatif $(\mathrm{Ha})$ yang diajukan "diterima" dan hipotesis nihil ( $\mathrm{Ho})$ "ditolak." Dengan demikian dapat diinterpretasikan bahwa ada Hubungan Power Otot Lengan Dan Kekuatan Genggaman Dengan Hasil Servis Slice Pada Permainan Tenis Lapangan Pada Mahasiswa FPOK IKIP Mataram Tahun 2016/2017. Heri Yogo Prayadi (2013) juga berpendapat bahwa Ada perbedaan pengaruh yang signifikan antara metode drill power otot lengan rendah dengan metode bermain power otot lengan rendah. Peningkatan keterampilan smash bulutangkis metode bermain power otot lengan rendah lebih baik dibandingkan dengan metode drill power otot lengan rendah. Terdapat pengaruh interaksi yang signifikan antara metode latihan dan power otot lengan terhadap peningkatan smash bulutangkis.

Beradasarkan informasi itu, maka peneliti tertarik melakukan suatu penelitian ilmiah, untuk mengetahui sejauh mana kemampuan servis panjang yang dimiliki oleh pemain di SMA Negeri 2 OKU. dengan begitu peneliti mengambil judul yaitu: Hubungan antara power otot lengan dan koordinasi mata-tangan dengan hasil servis panjang dalam permaian bulu tangkis pada siswa extrakurikuler SMA Negeri 2 OKU.

\section{Metode}

Metode Penelitian adalah cara yang dipakai dalam mengumpulkan data, sedang instrumen adalah alat bantu yang digunakan dalam mengumpulkan data itu (Arikunto, 2010:219). Metode yang dipakai dalam penelitian ini adalah metode korelasional,. Populasi adalah wilayah generalisasi yang terdiri atas: obyek/subyek yang mempunyai kualitas dan karakteristik tertentu yang ditetapkan oleh peneliti untuk dipelajari dan kemudian ditarik kesimpulannya (Sugiyono, 2011:80). Populasi di dalam penelitian ini adalah seluruh siswa peserta ekstrakurikuler SMA Negeri 2 OKU yang berjumlah 20 orang. Sampel adalah bagian dari populasi yang menjadi pusat perhatian penelitian kita, dalam ruang lingkup dan waktu yang kita tentukan (Winarno, 2011: 83). Berdasarkan keterangan tersebut untuk mendapatkan sampel yang tepat peneliti menggunakan teknik pengambilan sampel total sampling, dimana keseluruhan anggota populasi bisa semua dijadikan sampel penelitian. Jadi sampel dalam penelitian ini adalah keseluruhan dari anggota populasi yang berjumlah 20 siswa. Instrumen tes menurut Sugiyono (2012:102) adalah suatu alat yang digunakan untuk mengukur fenomena alam maupun sosial yang dimati, sementara Instrumen untuk mengumpulkan data. adapun instrumen-instrumen yang digunakan adalah (1). otot lengan. Menggunakan tes Two-Hand Medicine Ball Put, (Ismaryati, 2011) (2).Koordinasi matatangan Menggunakan tes lempar tangkap bola tenis, (Ismaryati, 2011:54) (3). Hasil servis panjang Menggunakan tes servis panjang, (Nurhasan,2001:181). Fitrek Hernado (2017) menyatakan bahwa Ada perbedaan pengaruh antara siswa yang memiliki powerotot lengan tinggi dan powerotot lengan rendah terhadap terhadap hasil tolak peluru pada 
peserta putra ekstrakurikuler SMP Negeri Kota Pagaralam Provinsi Sumatera Selatan Tahun 2015-2016

Teknik analisis data merupakan suatu cara yang digunakan untuk memperoleh atau menganalisis data-data yang diperoleh. Analisis tersebut bertujuan untuk kebenaran hipotesis yang dirumuskan, suatu hipotesis akan diterima atau ditolak tergantung dari analisis data. Dalam penelitian ini peneliti menggunakan analisis data dengan kolerasi product moment, korelasi ganda dan uji t.

\section{Hasil dan Pembahasan}

Pengolahan data hasil perhitungan melalui analisis statistik akan diperoleh jawaban mengenai diterima atau ditolaknya hipotesis sesuai dengan taraf nyata yang diajukan. Penelitan ini diharapkan dapat digeneralisasi sehingga perlu di uji normalitas data variable terikat. Data hasil penelitian masuk dalam kategori data tunggal sehingga pengujian normalitas data dilakukan dengan menggunakan rumus Liliefors. Dengan langkah-langkah yang ditempuh penulis adalah sebagai berikut:

Tabel. 1. Hasil pengujian normalitas data dengan uji lilliefors

\begin{tabular}{lccc}
\hline Jenis Tes & Lo & Ltabel & Hasil \\
\hline Power otot lengan & 0,09 & 0.190 & Normal \\
\hline Koordinasi mata-tangan & 0,05 & 0,190 & Normal \\
\hline Servis Panjang & 0.15 & 0,190 & Normal
\end{tabular}

Berdasarkan uji normalitas masing-masing variabel dengan menggunakan uji Liliefors. Diketahui data variabel bebas dan variabel terikat berdistribusi normal. Dengan menggunakan $\mathrm{k}=2$ sebagai $\mathrm{dk}$ pembilang dan $(\mathrm{n}-\mathrm{k}-1) 20-2-1=17$ sebagai dk penyebut, maka dalam distribusi $F$, nilai $F_{\text {tabel }}$ adalah sebesar 3,59. Jadi $F_{\text {hitung }}(5,886)>F_{\text {tabel }}(3,59)$, maka Ho ditolak dan ha diterima. Kesimpulannya adalah terdapat hubungan yang berarti antara power otot lengan $\left(X_{1}\right)$ dan koordinasi mata-tangan $\left(X_{2}\right)$ secara bersama-sama terhadap servis panjang bulu tangkis $(\mathrm{Y})$.

\section{Pembahasan Hasil Penelitian}

Pembahasan hasil dalam penelitian ini akan memberikan penafsiran yang lebih lanjut mengenai hasil analisis dan pengujian data yang telah diperoleh dari tes. Berdasarkan hasil analisis data maka power otot lengan memiliki hubungan yang signifikan terbukti power otot lengan memiliki korelasi sebesar 0,716 dan uji signifikan: Untuk kaidah pengujian jika $t_{\text {hitung }}>$ $t_{t a b e l}$, maka tolak $h_{0}$ artinya signifikan dan jika $t_{\text {hitung }}<t_{\text {tabel, }}$ terima $h_{0}$ artinya tidak signifikan. Berdasarkan perhitungan yang ada, maka untuk kesalahan $5 \% \mathrm{dk}=\mathrm{n}-2=18$ sehingga diperoleh $t_{\text {tabel }}=1,734$, ternyata $t_{\text {hitung }} 10,411$ lebih besar dari $t_{\text {tabel }} 1,734$, maka $h_{0}$ ditolak, artinya ada hubungan signifikan antara power otot lengan dengan hasil servis panjang pada peserta ekstrakurikuler SMA Negeri 2 OKU. Dan power otot lengan memberikan sumbangan sebesar $66,75 \%$ terhadap servis panjang.

Dilihat dari teori-teori yang telah dikutip dalam penelitian ini ada dua komponen kondisi fisik yaitu power otot lengan, dari hasil analisis data yang telah dilakukan terbukti bahwa antara power otot lengan dengan servis panjang memiliki hubungan yang sangat kuat. Bukti tersebut sebelumnya sudah disampaikan oleh para ahli yang menyatakan bahwa, Daya ledak (power) adalah kemampuan seseorang untuk mempergunakan kekuatan maksimum yang dikerahkan dalam waktu yang sesingkat-singkatnya (Halim, 2011:16). Dari kutipan tersebut dapat dikemukakan untuk mendapatkan hasil servis yang baik salah satu caranya yaitu dengan memaksimalkan kekuatan dan kecepatan otot lengan. Disaat pelaksanaan 
penelitian para pemain diberikan penjelasan terlebih dahulu tentang power, sehingga hasilnya terbukti bahwa dilapangan para pemain melakukan servis panjang dengan sekuat tenaga. Berdasarkan hasil penelitian ini membuktikan bahwa komponen kondisi fisik sangat berperan dari kemampuan melakukan servis panjang, terutama komponen power otot lengan. Maka dari itu peneliti berharap di SMA Negeri 2 OKU untuk terus memperhatikan komponen kondisi fisik ini karena sangat mempengaruhi hasil dalam melakukan servis panjang.

Berdasarkan hasil analisis data terbukti bahwa koordinasi mata-tangan memiliki korelasi sebesar 0,512 dengan servis panjang dan berdasarkan hasil uji sigifikan koordinasi yaitu: Untuk kaidah pengujian jika $t_{\text {hitung }}>t_{\text {tabel, }}$, maka tolak $h_{0}$ artinya signifikan dan jika $t_{\text {hitung }}<$ $t_{\text {tabel, }}$ terima $h_{0}$ artinya tidak signifikan. Berdasarkan perhitungan yang ada, maka untuk kesalahan $5 \% d k=n-2=18$ sehingga diperoleh $t_{\text {tabel }}=1,734$, ternyata $t_{\text {hitung }} 2,626$ lebih besar dari $t_{\text {tabel }} 1,734$, maka $h_{0}$ ditolak, artinya ada hubungan signifikan antara koordinasi matatangan dengan hasil servis panjang pada peserta ekstrakurikuler SMA Negeri 2 OKU. Dan koordinasi mata-tangan memberikan sumbangan sebesar $27,7 \%$ terhadap servis panjang.

Pembuktian ini didukung dengan pendapat Ahmadi (2007:66) mengemukakan koordinasi adalah kemampuan seseorang dalam mengintegrasikan atau menghubungkan bermacam-macam gerakan yang berbeda ke dalam bentuk gerakan tunggal secara efektif. Macam-macam gerakan dalam hal ini adalah mata dan tangan yang saling berkontraksi dalam rangka menghasilkan servis panjang yang tepat sasaran. Di saat penelitian terlihat ada sebagian yang memaksimalkan dan masih ada juga yang belum memaksimalkan koordinasi mata-tangan. Dengan adanya pembuktian tersebut di atas maka bagi pelatih atau guru diharapkan selalu memperhatikan koordinasi mata-tangan dalam melakukan servis panjang karena juga memiliki hubungan yang kuat bagi servis panjang.

Pembahasan hasil dalam penelitian ini akan memberikan penafsiran yang lebih lanjut mengenai hasil analisis dan pengujian data yang telah diperoleh dari tes. Korelasi antara power otot lengan $\left(\mathrm{X}_{1}\right)$, dan koordinasi mata tangan $\left(\mathrm{X}_{2}\right)$ dengan hasil servis panjang pada permainan bulutangkis $(Y)$ adalah $r_{X 1 Y}: 0,817, r_{X 2} Y_{: 0,526}, r_{X 1} X_{2}: 0,399$. Hubunga antar variabel signifikan setelah dilakukan analisis, dan anatar variabel power otot lengan memberikan sumbangan sebesar $66,75 \%$ terhadap servis panjang. Koordinasi mata-tangan memberikan sumbangan sebesar $27,7 \%$ terhadap servis panjang. Sedangkan secara bersama-sam power otot lengan dan koordinasi mata-tangan memberikan sumbangan sebesar $73,6 \%$.

Hasil penelitian telah membuktikan bahwa power dan koordinasi memiliki hubungan yang signifikan dengan servis panjang. Hubungan tersebut sejalan dengan pendapat para ahli, Muhajir (2005:67), mengemukakan dalam permainan bulu tangkis kemampuan servis mutlak dikuasai oleh pemain. Salah melakukan servis berarti fatal, sedangkan unggul dalam servis berarti membuka kemungkinan mendapatkan angka. Dari kutipan tersebut jelas dalam melakukan servis memerlukan komponen yang bisa meningkatkan kemampuan servis terutama servis panjang. Karena dengan memiliki servis yang baik besar kemungkinan akan mendapatkan angka.

Dengan adanya pembuktian tersebut maka perhatian harus selalu kedua komponen kondisi fisik tersebut, karena terbukti secara bersama-sama memiliki hubungan yang signifikan terhadap servis panjang.

\section{Simpulan dan Saran}

Berdasarkan hasil penelitian dan pembahasan, dapat disimpulkan Hubungan anatara power otot lengan $(\mathrm{X} 1)$ dengan servis panjang $(\mathrm{Y})$, hasil analisis data maka power otot lengan memiliki hubungan yang signifikan terbukti power otot lengan memiliki korelasi sebesar 0,716 dengan kateogri kuat. Uji signifikansi diperoleh thitung 10,411 lebih besar dari ttabel 1,734, sedangkan besaran sumbangan sebesar 66,75\%. Dengan demikian disimpulkan ada hubungan signifikan antara power otot lengan dengan hasil servis panjang pada peserta ekstrakurikuler SMA Negeri 2 OKU.

Hubungan antara koordinasi mata-tangan (X2) dengan servis panjang ( $Y$ ) hasil analisis data maka power otot lengan memiliki hubungan yang signifikan bahwa koordinasi 
mata-tangan memiliki korelasi sebesar 0,512 dengan kateogri sedang. Uji signifikansi diperoleh thitung 2,626 lebih besar dari ttabel 1,734, sedangkan besaran sumbangan sebesar $27,7 \%$.

Hubungan antara power otot lengan (X1) dan koordinasi mata-tangan (X2) dengan servis panjang $(Y)$ Korelasi antara power otot lengan $(X 1)$, dan koordinasi mata tangan $(X 2)$ dengan hasil servis panjang pada permainan bulutangkis $(\mathrm{Y})$ adalah $r \times 1 \mathrm{Y}: 0,817, \mathrm{rX2} \mathrm{Y}$ : 0,526, rX1 X2: 0,399. Hubungan antar variabel signifikan setelah dilakukan analisis, dan antara variabel power otot lengan memberikan sumbangan sebesar $66,75 \%$ terhadap servis panjang. Koordinasi mata-tangan memberikan sumbangan sebesar $27,7 \%$ terhadap servis panjang. Sedangkan secara bersama-sam power otot lengan dan koordinasi mata-tangan memberikan sumbangan sebesar $73,6 \%$.

\section{Daftar Pustaka}

Arikunto Suharsimi, 2010. Prosedur Penelitian Suatu Praktik, Jakarta : PT, Rineka Cipta.

Fitrek Hernado, Soekardi, Wahyu Lestari. 2017. Pengaruh Metode Latihan dan PowerOtot Lengan terhadap Hasil Tolak Peluru. Journal of Physical Education and Sports Uness. Volume 6, Nomor 1. (p) 22-28.

Ghon Lisdiantoro. 2016. Hubungan antara Koordinasi Mata Tangan, Power Otot Lengan dan Kekuatan Otot Perut dengan Kemampuan Pukulan Smash dalam Permainan Bulutangkis Premiere Educandum IKIP PGRI Madiun. Volume 6 Nomor 2. (p) 210 221.

Helda Heldayana, Aming Supriyatna, Iman Imanudin. 2016. Hubungan Antara Power Otot Lengan Dan Otot Tungkai Dengan Hasil Spike Semi Pada Cabang Olahraga Bola Voli. Jurnal Terapan Ilmu Keolahragaan. Vol.01 No.01. (p) 45-49.

Heri Yogo Prayadi, Hari Amirullah Rachman. 2013. Pengaruh Metode Latihan dan Power Lengan terhadap Kemampuan Smash Bulutangkis. Jurnal Keolahragaan UNY, Volume 1 Nomor 1.

Ismaryati, 2011. Tes \& Pengukuran Olahraga, Lembaga Pengembang Pendidikan (LPP) UNS dan UNS Press: Surakarta.

Maulidin. 2017. Hubungan Power Otot Lengan Dan Kekuatan Genggaman Dengan Hasil Servis Slice Pada Permainan Tenis Lapangan Pada Mahasiswa FPOK IKIP Mataram Tahun 2017. Jurnal IImiah Mandala Education (JIME). Vol 3, Nomor 1.

Muhajir. 2005. Pendidikan Jasmani Teori dan Praktek. Erlangga: Jakarta.

Muharam Syuhada. 2013. Hubungan Antara Power Otot Lengan Bahu, Kekuatan Otot Tungkai, Koordinasi Mata Tangan dengan Kemampuan Free Throw Pada Peserta Ekstrakurikuler Bolabasket di SMA N 1 Ngemplak Sleman. Jurnal Keolahragaan UNY. Volume 3 nomor 2.

Nurhasan, 2001. Tes dan Pengukuran dalam Pendidikan Jasmani. Jakarta; Direktorat Jenderal Olahraga.

Poole, James. 2011. Belajar Bulu Tangkis. Bandung: CV. Pionir Jaya. 
Indonesian Journal Of Educational Research and Review, Vol. 1 No. 2, Juli 2018 P-ISSN: 2621-4792, E-ISSN: 2621-8984

Sugiyono. 2011. Metode Penelitian Kuantitatif Kulitatif dan R\&D. Bandung: ALFABETA.

Widiastuti.2011. Tes dan Pengukuran Olahraga. Jakarta : PT Bumi Timur Jaya

Winarno. 2011. Metodologi Penelitian Dalam Pendidikan Jasmani. Malang: Media Cakrawala Utama Press. 